\title{
Delivery Outcome in Women with Major Sickle Cell Syndrome: A Comparative Study of the Homozygous Forms "SS" versus the Heterozygous "SC"
}

\author{
Amah Biova Adama-Hondégla ${ }^{*}$, Abdoul-Samadou Aboubakari², Kossi Edem Logbo-Akey², \\ Kodjo Fiagnon", Akila Bassowa $^{2}$, Koffi Akpadza' \\ ${ }^{1}$ Department of Gynecology and Obstetrics of the Sylvanus Olympio University Hospital of Lomé, Lomé, Togo \\ ${ }^{2}$ Department of Gynecology and Obstetrics of the University Hospital of Kara, Kara, Togo \\ Email: *rocadama@yahoo.fr
}

Received 16 September 2015; accepted 25 October 2015; published 28 October 2015

Copyright (C) 2015 by authors and Scientific Research Publishing Inc.

This work is licensed under the Creative Commons Attribution International License (CC BY).

http://creativecommons.org/licenses/by/4.0/

cC) (i) Open Access

\section{Abstract}

Objectives: To determine the prevalence of women who delivered in the two major sickle cell syndromes, "SS" and "SC", and to identify maternal and early neonatal prognosis inherent to each form. Material and Methods: This is a comparative, descriptive and retrospective cross-sectional study of 226 files of women carrying major sickle cell syndrome (66 cases of "SS" form versus 160 cases of "SC" form), collected from May 2008 to May 2013 at the Gynecology and Obstetrics Clinic of the Sylvanus Olympio's University Hospital of Lomé. Data were processed by Epi Info 6 software. For comparison of variables, the Chi-2 test of Fisher with significance as $p<0.05$ has been used, so is the calculation of Odds Ratio with its confidence interval at $95 \%$. Results: Carriers of the two major sickle cell syndromes represent $0.8 \%$ of all the deliveries during the study period. Caesarean section, especially prophylactic one, was the dominant mode of delivery. The SS forms have been exposed to have more vaso-occlusive crises $(22.7 \%$ vs. $13.1 \%$; $p=0.04,0 R=0.31)$, more blood transfusion $\left(57.6 \%\right.$ vs. $\left.29.4 \% ; p=7 \times 10^{-5}, 0 R=3.2\right)$ and more puerperal infections $(p<0.05)$. Acute chest syndrome was not related to any of the two forms of sickle cell disease $(13.6 \%$ vs. $8.1 \% ; p=0.15$ ). The maternal mortality rate and the perinatal mortality among SS form against SC form were not significant (respectively $15.1 \%$ vs. $8.7 \%$; $20.9 \%$ vs. $17.1 \%$ ). Conclusion: Maternal and fetal complications were present in both forms of major sickle cell syndrome but the "SS" form gave exposure to greater maternal morbidity. Resuscitative measures in adults and newborns should be reinforced at the delivery time of these "at-risk-pregnancies".

\footnotetext{
${ }^{*}$ Corresponding author.
}

How to cite this paper: Adama-Hondégla, A.B., Aboubakari, A.-S., Logbo-Akey, K.E., Fiagnon, K., Bassowa, A. and Akpadza, K. (2015) Delivery Outcome in Women with Major Sickle Cell Syndrome: A Comparative Study of the Homozygous Forms "SS" versus the Heterozygous "SC". Open Journal of Obstetrics and Gynecology, 5, 713-722. 


\section{Keywords}

Sickle Cell Disease, Childbirth, Prognosis, Homozygous SS, Heterozygous SC, Togo, Africa

\section{Introduction}

Sickle cell disease is a genetic disorder of the hemoglobin $(\mathrm{Hb})$ characterized by the presence of an abnormal hemoglobin, highly concentrated in red blood cells. It is an autosomal recessive disease caused by mutation of the $\beta$-globin gene (substitution of valine for glutamic acid at position six in the $\beta$ chain of hemoglobin-globin), responsible for the synthesis of the pathological hemoglobin " $\mathrm{S}$ " $(\mathrm{HbS})$. The structural modification of the hemoglobin then promotes its polymerization which leads the red blood cell to sickling and then to microvascular occlusions [1] [2].

The term "sickle cell syndrome" initially restricted to "SS" homozygous subjects also relates now to compound heterozygous $\mathrm{SC}$ and $\mathrm{S} \beta$ thalassemia. Sickle cell syndrome with the thalassemia represents the most common genetic diseases in the world and preferably among black populations [3]. The pathological hemoglobin " $\mathrm{C}$ " $(\mathrm{HbC})$ also comes to sickle because of its glutamic acid to lysine substitution at position six in the $\beta$-globin chain. People with hemoglobin " $\mathrm{C}$ " are localized concentrically to the whole voltaic tray region of West Africa, where heterozygosity SC can be as found as homozygosis SS [4]. Individuals who are homozygous for the sickle cell hemoglobin (HbSS) or heterozygous (HbSC) have various signs and symptoms that characterize the two forms of the disease.

In 2011, the World Health Organization estimated that 5\% of the world population carried the characteristic genes of this type of hemoglobin disease [5]. In West Africa, $30 \%$ to $40 \%$ of the population is concerned [6] with these genes.

Formerly discouraged, motherhood has increased among women with major sickle cell syndrome because of the considerable progress made in the management of this disease [7]. Whether in homozygous "SS" or in composite forms as heterozygous "SC", pregnancy, childbirth and the postpartum period remain a high-risk situation. This is due to chronic hypoxia and vaso-occlusive phenomena that occur in the microcirculation, both maternal and fetal [8]. Pregnancy allows acute complications such as sickle cell vaso-occlusive crises, acute chest syndrome, or severe chronic anemia [9]. Maternal death rate due to sickle cell diseases in pregnancy is up to $11.4 \%$ [10]. Fetal death in utero, intrauterine growth restriction, prematurity, acute fetal distress and intrapartum fetal death are common [9].

In Togo, about $16.1 \%$ of the population is affected by sickle cell disease (homozygous forms "SS" are $1.3 \%$ and heterozygous forms "SC" are about $2.6 \%$ ) and each year, approximately 6000 new births affected by sickle cell disease are recorded [11] [12]. Sylvanus Olympio teaching hospital's maternity is to date the first reference center in Lomé (Togo) in sickle cell disease management during pregnancy.

No studies illustrating the influence of each form (SS and SC) on maternal and perinatal prognosis are available. This work was initiated in an effort to help improve the prognosis of delivery of major sickle cell syndrome carriers. It aims to compare maternal and neonatal prognosis of delivery between the SS homozygous and SC heterozygous.

\section{Materials and Methods}

This study was conducted at the Gynecologic and Obstetrics Clinic of Sylvanus Olympio University Hospital of Lomé. This clinic is currently the first national reference center for diagnosis and management of hemoglobin disorders during pregnancy. It is a rank "A" maternity, providing full emergency obstetrical and neonatal care (full EmONC) and receiving patients referred from various health facilities in Togo.

According to the protocol of the service, in terms of pregnancy associated with major sickle cell disease, an elective caesarean section was systematically done for each term of pregnancy exceeding 36 weeks of amenorrhea, unless childbirth was imminent (cervical dilatation was $\geq 7 \mathrm{~cm}$ and fetal presentation was eutocic and engaged). If the hemoglobin level was $<9$ grams/deciliter during childbirth or in case of cesarean delivery, blood transfusion was done systematically in these patients with two bags of 450 milliliters of packed red blood cells. Inpost-partum or post-operatively, the protocol recommended a double prophylactic antibiotic (Ceftriaxone or 
Clavulanic acid-Amoxicillinplus Metronidazole) associated with a low molecular weight heparin (4000 IU Enoxaparin sodium subcutaneously per day for at least 6 days).

According to the organization of the health system, outside of the kit of caesarean operation which was subsidized, all other emergency medications were facing the responsibility of parents accompanying the patient. They were required to bring from the pharmacy, the prescribed products before starting the emergency care. At the time of this study, blood exchange transfusions were not performed during pregnancy or childbirth in women with sickle cell disease in the center.

This study is a cross-sectional comparative and retrospective study conducted over a period of 5 years (from May 2008 to May 2013). Two hundred and twenty-six (226) birth records files from major sickle cell anemia mothers (SS or SC) were collected.

Were included in this study: the records files of all sickle cell SS and SC women who delivered during the study period in the Gynecologic and Obstetrics Clinic of Sylvanus Olympio University Hospital. The diagnosis of the two major sickle cell disease SS and SC was affirmed by electrophoresis of hemoglobin (part of prenatal assessment). Were included, all women with a gestational age at/or greater than 28 weeks of amenorrhea and carrying the two major sickle cell disease.

The variables studied were the socio-demographic aspect and the maternal and neonatal prognosis. Data collection was made with a pre-established survey form document by reviewing obstetrical records, admission and hospitalization records of the Gynecologic and Obstetrics Clinic of Sylvanus Olympio University Hospital and those of the neonatology service.

\section{Statistical Analysis}

The data were processed with EPIINFO software 7. The "Chi 2" Exact Test of Fischer was applied to establish significance between variables (if $p$ value $<0.05$ ). The calculation of Odds Ratio (OR) has been used to estimate the correlation among significant variables. The results were expressed with a confidence interval (CI) of Odds Ratio at $95 \%$.

\section{Results}

\subsection{Prevalence of Sickle Cell Delivery}

During the 5 years, it was recorded 27951 deliveries of which 226 from women with the two major hemoglobin diseases; a total prevalence of $0.8 \%$. Among women with sickle cell disease, there was $66(0.23 \%)$ of SS group and $160(0.57 \%)$ of SC group.

\subsection{Socio-Demographic Data}

Age, profession and education level data were represented in Table 1. The average age in homozygous SS was 25.43 years with extremes of 18 and 40 years. In heterozygous SC, the average age was 26.95 years with extremes of 17 and 42 years. As far as education is concerned, the secondary level was most represented in both groups.

According to Table 1, childbirth in major sickle cell syndrome occurred in most young women (less or equal to 30 years with secondary level education (in the two groups) and low socio economic status (there were a high proportion of housewives in "SS" forms and enough liberal profession in the two groups).

\subsection{Maternal Prognosis}

Prematurity and route of delivery depending on the type of sickle cell disease are shown in Table 2. The type of sickle cell disease did not influence the pregnancy term of delivery $(\mathrm{p}<0.05)$; the majority of SS patients $(68.2 \%)$ and $\mathrm{SC}(76.9 \%)$ had given birth at term (over 37 weeks of amenorrhea).

Upon admission to maternity, $47 \%$ of patients SS against $57.5 \%$ SC were already in labor. The type of sickle cell disease did not influence significantly $(\mathrm{p}<0.05)$ the mode of delivery.

Among the proportion of women who delivered by cesarean section, prophylactic caesarean was rated significantly $(\mathrm{p}=0.02 ; \mathrm{OR}=2.12)$ in sickle cell SS $(59.2 \%)$ than SC $(40.6 \%)$. The indications for emergency caesarean section are reported in Table 3. According to this table, the indications relating to vaso-occlusive crises, severe preeclampsia and eclampsia have been significantly influenced by the "SS" type of sickle cell disease. 
Table 1. Socio-demographic characteristics according to the type of sickle cell disease.

\begin{tabular}{ccc}
\hline SS & SC \\
$\mathrm{N}=66$ & $\mathrm{~N}=160$ & $\mathrm{p}$ values \\
$(\%)$ & $\mathrm{n}(\%)$ & \\
\hline
\end{tabular}

Age (years)

$\begin{array}{lccc}\leq 19 & 10(15.2) & 15(9.4) & 0.152 \\ {[20-24]} & 19(28.8) & 41(25.6) & 0.369 \\ {[25-29]} & 25(37.8) & 56(35.0) & 0.396 \\ {[30-34]} & 10(15.2) & 33(20.6) & 0.223 \\ {[35-39]} & 0(0.0) & 12(7.5) & 0.013^{*} \\ \geq 40 & 2(3.0) & 3(1.9) & 0.456\end{array}$

Education level

$\begin{array}{lccc}\text { Primary } & 18(27.4) & 37(23.1) & 0.308 \\ \text { Secondary } & 36(54.5) & 85(53.1) & 0.481 \\ \text { University } & 3(4.5) & 21(13.1) & 0.041^{*} \\ \text { Illiterate } & 9(13.6) & 17(10.6) & 0.331\end{array}$

Profession

\begin{tabular}{lccc} 
Housewife & $33(50.0)$ & $35(21.9)$ & $3 \times 10^{-5^{*}}$ \\
Liberal profession & $21(31.8)$ & $51(31.9)$ & 0.562 \\
Civil servant & $4(6.1)$ & $29(18.1)$ & $0.012^{*}$ \\
Retailer & $8(12.1)$ & $45(28.1)$ & $0.006^{*}$ \\
\hline
\end{tabular}

${ }^{*} \mathrm{p}<0.005$ : the comparison was significant between those variables.

Table 2. Gestational age at childbirth and route of delivery according to the type of sickle cell disease.

\begin{tabular}{|c|c|c|c|c|}
\hline & $\begin{array}{c}\mathrm{SS} \\
\mathrm{N}=66\end{array}$ & $\begin{array}{c}\mathrm{SC} \\
\mathrm{N}=160\end{array}$ & \multirow[t]{2}{*}{$\mathrm{p}$ values } & \multirow[t]{2}{*}{$\begin{array}{c}\text { CI for odds ratio } \\
\text { at } 95 \%\end{array}$} \\
\hline & $\mathrm{n}(\%)$ & $\mathrm{n}(\%)$ & & \\
\hline \multicolumn{5}{|c|}{$\begin{array}{l}\text { Gestational Age } \\
\text { (weeks of amenorrhea: WA) }\end{array}$} \\
\hline \multicolumn{5}{|l|}{ Childbirth before 32 WA } \\
\hline$<32$ WA & $5(7.6)$ & $8(5.0)$ & \multirow{2}{*}{0.318} & \multirow{2}{*}{ Not significant } \\
\hline$\geq 32 \mathrm{WA}$ & $61(92.40)$ & $152(95.0)$ & & \\
\hline \multicolumn{5}{|l|}{ Childbirth before $37 \mathrm{WA}$} \\
\hline$<37 \mathrm{WA}$ & $21(31.8)$ & $37(23.1)$ & \multirow[b]{2}{*}{0.117} & \multirow{2}{*}{ Not significant } \\
\hline$\geq 37 \mathrm{WA}$ & $45(68.2)$ & $123(76.9)$ & & \\
\hline \multicolumn{5}{|l|}{ Mode of delivery } \\
\hline Caesarean section & $49(74.2)$ & $106(66.3)$ & \multirow[b]{2}{*}{0.153} & \multirow[b]{2}{*}{ Not significant } \\
\hline Vaginal route & $17(25.8)$ & 54 (33.7) & & \\
\hline
\end{tabular}


Table 3. Indications for emergency caesarean section.

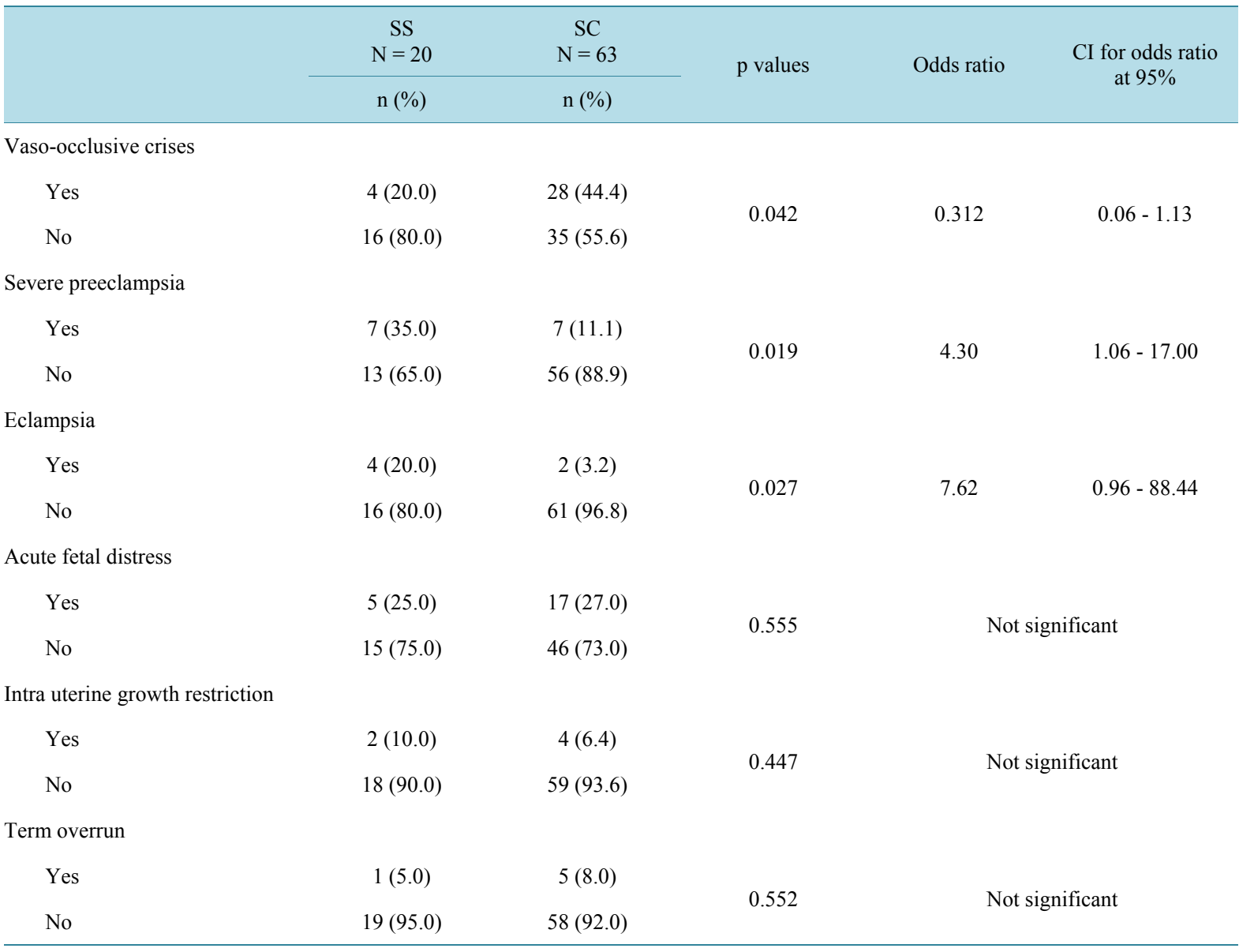

\subsection{Complications of Postpartum Period}

In postpartum period, many complications were found according to the type of sickle cell disease and have been collected in Table 4. Anemia, vaso-occlusive crises and urinary tract infectious complications were found more in sickle cell SS than SC $(p<0.05)$. The type of sickle cell disease did not influence the onset of acute chest syndrome or eclampsia.

\subsection{Blood Transfusion-Maternal Survival}

According to the results in Table 5, SS sickle cell carriers were more transfused than SCones ( $p=0.00007$; OR $=3.2$ ) and the type of sickle cell disease did not influence the vital prognosis of the mothers $(p<0.05)$. The maternal mortality rate was $15.1 \%$ in the SS genotype against $9.7 \%$ in the SC genotype.

\subsection{Cause of Maternal Deaths}

The various causes of maternal deaths were listed in Table 6. The main causes of maternal death were acute chest syndrome with a respective $40 \%$ and $35.7 \%$ for SS and SC ( $p<0.581$; not significant), anemia and decompensation with respective rates of $30 \%$ and $28.6 \%$ among sickle cell SS and SC.

\subsection{Neonatal Prognosis}

During the period of the study, it was recorded 67 births in SS sickle cell (65 singleton births with one twin birth) and 164 births in sickle cell SC (156 singleton births with 4 twin births). The status of the fetus at birth was reported in Table 7. It has been noticed more deaths in utero for SC sickle cell than for the SS ones $(7.9 \%$ vs. 
Table 4. Postpartum period complications in relation to type of sickle cell disease.

\begin{tabular}{|c|c|c|c|c|c|}
\hline & $\begin{array}{c}\mathrm{SS} \\
\mathrm{N}=66\end{array}$ & $\begin{array}{c}\mathrm{SC} \\
\mathrm{N}=160\end{array}$ & \multirow[t]{2}{*}{$\mathrm{p}$ values } & \multirow[t]{2}{*}{ Odds ratio } & \multirow{2}{*}{$\begin{array}{c}\text { CI for odds ratio } \\
\text { at } 95 \%\end{array}$} \\
\hline & $\mathrm{n}(\%)$ & $\mathrm{n}(\%)$ & & & \\
\hline \multicolumn{6}{|l|}{ Anemia } \\
\hline Yes & $29(43.9)$ & $33(20.6)$ & \multirow[b]{2}{*}{0.0004} & \multirow[b]{2}{*}{3.01} & \multirow[b]{2}{*}{$1.54-5.85$} \\
\hline No & $37(56.1)$ & $127(79.4)$ & & & \\
\hline \multicolumn{6}{|c|}{ Vaso-occlusive crises } \\
\hline Yes & $15(22.7)$ & $21(13.1)$ & \multirow[b]{2}{*}{0.058} & \multirow[b]{2}{*}{1.94} & \multirow[b]{2}{*}{$0.85-4.30$} \\
\hline No & $51(77.3)$ & $139(86.9)$ & & & \\
\hline \multicolumn{6}{|c|}{ Acute chest syndrome } \\
\hline Yes & $9(13.6)$ & $13(8.1)$ & \multirow{2}{*}{0.152} & \multirow{2}{*}{\multicolumn{2}{|c|}{ Not significant }} \\
\hline No & $57(86.4)$ & $147(91.9)$ & & & \\
\hline \multicolumn{6}{|c|}{ Urinary infection } \\
\hline Yes & $7(10.6)$ & $5(3.1)$ & \multirow[b]{2}{*}{0.029} & \multirow[b]{2}{*}{3.67} & \multirow[b]{2}{*}{$0.95-15.20$} \\
\hline No & $59(89.4)$ & $155(96.9)$ & & & \\
\hline \multicolumn{6}{|c|}{ Endometritis } \\
\hline Yes & $4(6.1)$ & $1(0.6)$ & \multirow[b]{2}{*}{0.026} & \multirow[b]{2}{*}{10.25} & \multirow[b]{2}{*}{$0.97-508.24$} \\
\hline No & $62(93.9)$ & 159 (99.4) & & & \\
\hline \multicolumn{6}{|c|}{ Eclampsia } \\
\hline Yes & $7(10.6)$ & $17(10.6)$ & \multirow[t]{2}{*}{0.585} & \multirow{2}{*}{\multicolumn{2}{|c|}{ Not significant }} \\
\hline No & $59(89.4)$ & $143(89.4)$ & & & \\
\hline \multicolumn{6}{|c|}{ Cerebral venous sinus thrombosis } \\
\hline Yes & $1(1.5)$ & $4(2.5)$ & \multirow[b]{2}{*}{0.543} & \multirow{2}{*}{\multicolumn{2}{|c|}{ Not significant }} \\
\hline No & $65(98.5)$ & $156(97.5)$ & & & \\
\hline
\end{tabular}

Table 5. Blood transfusion requirements and maternal survival at hospital discharge.

\begin{tabular}{|c|c|c|c|c|c|}
\hline & $\begin{array}{c}\mathrm{SS} \\
\mathrm{N}=66\end{array}$ & $\begin{array}{c}\mathrm{SC} \\
\mathrm{N}=160\end{array}$ & \multirow[t]{2}{*}{$\mathrm{p}$ values } & \multirow[t]{2}{*}{ Odds ratio } & \multirow{2}{*}{$\begin{array}{c}\text { CI for odds ratio } \\
\text { at } 95 \%\end{array}$} \\
\hline & $\mathrm{n}(\%)$ & $\mathrm{n}(\%)$ & & & \\
\hline \multicolumn{6}{|l|}{ Transfusion } \\
\hline Transfused & $38(57.6)$ & $47(29.4)$ & \multirow[b]{2}{*}{0.00007} & \multirow[b]{2}{*}{3.26} & \multirow[b]{2}{*}{$1.72-6.18$} \\
\hline Not transfused & $28(42.4)$ & $113(70.6)$ & & & \\
\hline \multicolumn{6}{|c|}{ State at discharge from hospital } \\
\hline Dead & $10(15.1)$ & $14(8.7)$ & \multirow[b]{2}{*}{0.119} & \multirow{2}{*}{\multicolumn{2}{|c|}{ Not significant }} \\
\hline Alive & $56(84.9)$ & $146(91.3)$ & & & \\
\hline
\end{tabular}


Table 6. Cause of maternal deaths in relation to sickle cell disease.

\begin{tabular}{cccc}
\hline Cause of maternal deaths & $\mathrm{SS}$ & $\mathrm{SC}$ & $\begin{array}{c}\mathrm{p} \text { values } \\
\text { (not significant) }\end{array}$ \\
\hline Anemic decompensation & $\mathrm{N}(\%)$ & $4(28.6)$ & 0.643 \\
Cerebral venous sinus thrombosis & $3(30.0)$ & $2(14.3)$ & 0.329 \\
Hemorrhagic stroke & $0(0.0)$ & $2(14.3)$ & 0.563 \\
Hypertensive encephalopathy & $2(20.0)$ & $1(7.1)$ & 0.583 \\
Acute chest syndrome & $0(0.0)$ & $5(35.7)$ & 0.581 \\
Septic shock & $4(40.0)$ & $0(0.0)$ & 0.454
\end{tabular}

Table 7. Neonatal prognosis.

\begin{tabular}{|c|c|c|c|c|c|}
\hline & $\begin{array}{c}\mathrm{SS} \\
\mathrm{N}=67\end{array}$ & $\begin{array}{c}\mathrm{SC} \\
\mathrm{N}=164\end{array}$ & \multirow[t]{2}{*}{$\mathrm{p}$ values } & \multirow[t]{2}{*}{ Odds ratio } & \multirow[t]{2}{*}{$\begin{array}{c}\text { CI for odds ratio } \\
\text { at } 95 \%\end{array}$} \\
\hline & $\mathrm{n}(\%)$ & $\mathrm{n}(\%)$ & & & \\
\hline \multicolumn{6}{|c|}{ Low birth weight } \\
\hline$<2500 \mathrm{~g}$ & $29(43.3)$ & $44(26.8)$ & \multirow{2}{*}{0.011} & \multirow{2}{*}{2.08} & \multirow{2}{*}{$1.09-3.92$} \\
\hline$\geq 2500 \mathrm{~g}$ & $38(56.7)$ & $120(73.2)$ & & & \\
\hline \multicolumn{6}{|l|}{ Died in utero } \\
\hline Yes & $1(1.5)$ & $13(7.9)$ & \multirow{2}{*}{0.050} & \multirow{2}{*}{0.17} & \multirow{2}{*}{$0.00-1.22$} \\
\hline No & $66(98.5)$ & $151(92.1)$ & & & \\
\hline \multicolumn{6}{|l|}{ Stillbirth } \\
\hline Yes & $4(6.0)$ & 17 (10.4) & \multirow{2}{*}{0.214} & \multirow{2}{*}{\multicolumn{2}{|c|}{ Not significant }} \\
\hline No & $63(94.0)$ & $147(89.6)$ & & & \\
\hline \multicolumn{6}{|c|}{$\begin{array}{l}\text { Early neonatal deaths } \\
\text { (within } 7 \text { days after birth) }\end{array}$} \\
\hline Yes & $10(15.6)$ & $11(7.5)$ & \multirow{2}{*}{0.046} & \multirow{2}{*}{2.44} & \multirow{2}{*}{$0.87-6.68$} \\
\hline No & $57(84.4)$ & $153(92.5)$ & & & \\
\hline \multicolumn{6}{|c|}{ Perinatal mortality } \\
\hline Dead & $15(20.9)$ & $41(17.1)$ & \multirow{2}{*}{0.423} & \multirow{2}{*}{\multicolumn{2}{|c|}{ Not significant }} \\
\hline Alive & $52(79.1)$ & $123(82.9)$ & & & \\
\hline
\end{tabular}

$1.5 \% ; \mathrm{p}<0.05)$. Perinatal mortality was 209 per 1000 births among the SS as against 171 per 1000 births among the SC form. Compared with SC sickle cell, the SS sickle cell carriers have given birth to more children whose weights were less than $2500 \mathrm{~g}(\mathrm{p}<0.011$; OR $=2.08)$.

\section{Discussion}

The retrospective nature of this study has, somehow, limited some aspects of the prognosis of delivery among major sickle cell disease women. Because many biological analysis (as liver, kidneys and blood coagulation explorations) were not available in most of the recorded files. The comparison of these analysis in the two groups could have enlarged the chances of findings in this study on sickle cell disease women's delivery.

During the study period, $0.80 \%$ of deliveries performed in the center concerned women with major sickle cell disease, $0.23 \%$ of SS against $0.57 \%$ of SC. There were a preponderance of the heterozygous form SC; as it had 
already been reported by Rahimy et al. [13] in Benin and Addai et al. [14] in Ghana. The high mortality of SS sickle cell subjects compared to SC sickle cell could be explained by the fact that very few SS sickle cell patients usually reach the age of motherhood. Each year, more than 500,000 children are born with sickle cell disease, including 300000 in Africa, half of all children in Africa will die before the age of 5 years [4].

In socio-demographic terms, the age range of 25 - 29 was the most represented in both groups with a mean age of 25.43 years for SS mothers against 26.95 years for SC. These results are similar to those of Muganyizi and Kidanto [10] in Tanzania but they are still low, compared to those of Rahimy et al. [13] (28 years for SS and 27.9 years for SC). Although studies have shown a lowering of the age at first menstruation in sickle cell, it did not show an impact of the disease on the age at first pregnancy [15] [16].

Sickle cell disease being a chronic illness, financial support remains heavy and often at the charge of the family especially those with socially disadvantaged background [17]. This financial support is most often done to the detriment of schooling; this could help to refer to the high proportion of secondary school level women in both series. Furthermore, repeated absences from work (due to the frequent hospitalization) can destabilize professional life leading to casualization and difficulties in finding a stable job. Accordingly, housewives were more represented in group SS (50\%) than SC (21.9\%) where the disease is less disabling and sometimes fortuitously discovered. The type of sickle cell disease did not affect the term of pregnancy at childbirth $(p>0.05)$; the majority of both SS and SC patients had carried their pregnancies to term. At the admission time in maternity for childbirth, $47 \%$ of sickle cell SS were in labor against $57.5 \%$ of SC. Caesarean section rate was $74.2 \%$ among SS against $66.3 \%$ among SC. The SC sickle cell disease women were in childbirth labor at the time of their admission to maternity $(57.5 \%$ vs. $47 \%$; $p>0.05)$ and have had more deaths in utero $(7.9 \%$ vs. $15 \% ; p=0.05)$. This could be explained by the fact that they have had fewer caesarean sections in emergency, compared to those with SS form. However, the caesarean section rate in this study was similar to that found by Ngo et al. [18] (73.6\%) but it is still high, compared to the literature data [13] [19]. The high rate of caesarean section found in this study relates to the protocol of the Gynecology and Obstetrics' service in the hospital, which recommended prophylactic caesarean section in any major sickle cell disease women from 37 weeks of amenorrhea. Indeed caesarean was scheduled in 59.2\% of cases of SS sickle cell and $40.5 \%$ of cases of SC sickle cell. In emergency, the type of sickle cell disease influenced the caesarean indications. SS sickle cell were more operated for severe preeclampsia $(35 \%$ vs. $11.1 \% ; \mathrm{p}=0.01)$ and eclampsia $(20 \%$ vs. $3.2 \% ; \mathrm{p}=0.02)$ than SC sickle cell. On the contrary, there were many more vaso-occlusive crises as an indications of caesarean section in SC sickle cell than in SS ones $(44.4 \%$ vs. $20 \%$; $\mathrm{p}=0.04)$.

Complications were more common in puerperium in sickle cell SS than SC $(65.2 \%$ vs. $30 \% ; \mathrm{p}=0.000001)$. These complications are anemia $(43.9 \%$ vs. $20.6 \% ; p=0.0004)$, vaso-occlusive crises $(22.7 \%$ vs. $13.1 \% ; p=$ $0.05)$, urinary tract infection and endometritis $(8.3 \%$ vs. $1.9 \% \mathrm{p}=0.02)$. Acute chest syndrome and eclampsia were found in both SS and SC forms ( $p>0.05)$. Leborgne-Samuel et al. [20] have noticed that the acute chest syndrome was present in both forms but with greater frequency in SS (21\% vs. 3.3\%). This is a serious complication of sickle cell disease which would be observed, according to Maitre et al. [21] and Vishinsky et al. [22] studies, more frequently in the SS form, inducing a mortality of $9 \%$ to $25 \%$. In this study, acute chest syndrome has been the leading cause of death in postpartum ( $40 \%$ of SS and $35.71 \%$ of SC). It occurs mostly after surgery and is favored by alveolar hypoventilation, hypo hydration, infections and post-operative pain. This implies the need for better management by the anesthesiologist and the mastering resuscitation technics in delivery of women with major sickle cell syndrome.

According to several authors [23] [24], most postpartum complications occurring in sickle cell syndrome could be prevented through prophylactic blood transfusion. In this study, despite the service protocol recommending systematic transfusion to sickle cell patient, only $57.6 \%$ of SS patient against $29.4 \%$ of SC were transfused $(\mathrm{p}=0.00007, \mathrm{OR}=3.2)$. The lack of financial support, the fear of being transfused and the shortage of blood products at the blood bank of the Sylvanus Olympio University Hospital or at the National Blood Transfusion Centre, might account for this. This tendency to transfuse more SS sickle cell in postpartum was also noticed by Rahimy et al. (54.8\% vs. 33.3\% SS) [13] and Leborgne-Samuel et al. (64\% SS vs. 3.3\%) [20]. the use of blood transfusion to improve the prognosis of pregnancy and childbirth in sickle cell remains controversial. Howard et al. [24] recommended transfusions from 28 weeks of amenorrhea to reduce the maternal and fetal complications in the $3^{\text {rd }}$ quarter and in the postpartum period. For Koshy et al. [23], systematic transfusion would be appreciated prior to 28 weeks of amenorrhea for patients with a history of perinatal mortality, preeclampsia, acute chest syndrome, stroke or severe anemia; to reduce the risk of infection and alloimmunization, 
which complicate subsequent transfusions. But for El Shafei et al. [25], systematic transfusion cannot improve the obstetric prognosis.

In postpartum, maternal death can be sudden and unexplained or occur in a particular context of management difficulties. It has been recorded during the study period, $15.1 \%$ of maternal death among the SS group against $8.7 \%$ among the SC $(p=0.11)$. Maternal deaths were also reported by other authors [10] [26] [27], making the sickle cell disease a major public health problem for both mothers and newborns. Of 231 births performed during the study period, 67 were from SS genotype mothers and 164 from SC genotype. Fetuses from SC mothers died more than those from SS mothers $(7.5 \%$ vs. $1.5 \% ; \mathrm{p}=0.05, \mathrm{OR}=0.17)$. In contrast to these results, more deaths were noticed in utero among SS sickle cell in the studies of Koshy et al. [23] (12\% vs. 0.0\%), Rahimy et al. $[13]$ (21\% vs. $6 \%)$.

At birth, most newborns from SS sickle cell mothers weighed less than $2500 \mathrm{~g}(43.3 \%$ vs. $26.8 \%$; $\mathrm{p}<0.01$, $\mathrm{OR}=2.08$ ). Many studies have also noted that newborns from SS mothers weigh less than those from SC mothers; this neonatal weight difference between the two forms (SS and SC) had been found by some authors [14] [18] and is probably caused by chronic anemia which seems to be much observed in SS sickle cell syndrome.

The perinatal mortality rate in this study was $20.9 \%$ among newborns from SS mothers against $17.1 \%$ among SC mothers. These rates are similar to those of Ogedengbe et al. [28] (23.3\% vs. 11.1\%), Idrissa et al. [29] (19.5\% in HC) and Ashish et al. [30] (20\%). Apart from sickle cell disease, some other factors involved in neonatal prognosis could have also influenced the neonatal outcome in this study. The need for systematic monitoring of infant born from major sickle cell mothers in neonatal emergency care unit should be rigorous and the hemoglobin electrophoretic testing of these newborns should be made from the 5th month of life [31].

\section{Conclusion}

According to the study, women carrying the two types of sickle cell disease have been generally affected by complications of childbirth. The carriers of the SS forms have been more at risk of pre-eclampsia, anemia, transfusion, low birth weight and puerperal infection. Maternal mortality was high in both forms and was attributable to acute chest syndrome and decompensation of severe anemia. Perinatal mortality was also very high. More emphasis must be put on pregnancy planning among these women (especially SS forms) and on providing a multidisciplinary monitoring including the hematologist, the resuscitator, the obstetrician and the pediatrician.

\section{References}

[1] Lionnet, F., Stankovic, K. and Girot, R. (2009) Drépanocytose de l'adulte. EMC-Hématologie, 4, 1-19. http://dx.doi.org/10.1016/S1155-1984(09)49949-7

[2] Haute Autorité de Santé (2005) Recommandations pour la pratique clinique. Prise en charge de la drépanocytose chez l'enfant et l'adolescent. Saint-Denis, P 16107.

http://lesouriredeselasse.free.fr/telechargement/Drepanocytose-rapport-HAS.pdf

[3] Constant, I. (1997) Drépanocytose et anesthésie. In: conférences d'actualisation SFAR, Paris, 33-55. http://www.sfar.org/acta/dossier/archives/ca97/html/ca97 003/97 03.htm

[4] Aubry, P. and Gauzere, B.A. (2014) Hémoglobinoses, Actualités 2014, Médecine Tropicale. http://medecinetropicale.free.fr/cours/hemoglobinoses.pdf

[5] WHO Media centre (2011) Drépanocytose et autres hémoglobinopathies. Aide-mémoire №308. http://www.who.int/mediacentre/factsheets/fs308/fr/

[6] Janky, E., Etienne-Julian, M., Kadhel, P.-H., Leborgne-Samuel, Y. and Melki, E. (2006) Drépanocytose et grossesse, Extrait des Mises à jour en Gynécologie et obstétrique, Tome XXX 29-38. http://www.cngof.asso.fr

[7] La Rosa, J. (2008) Prise en charge multi-disciplinaire des parturientes drépanocytaires Hb SC: Etude d'une cohorte et revue de la littérature Académie de Paris. Mémoire de DES. http://desar.org/Documents/Memoires/2008/Julien_Larosa.pdf

[8] Mandji-Lawson, J.M., Pither-Antchoue, S., Mouguengui, D., Mouloungui, S.P.E., Sima, Z.A, Tchoua, R. and Ngaka Nsafu, D. (2013) Complications of Sickle Cell Disease in Pregnant Patients: Two Cases Report of Acute Chest Syndrome. Extrait du SARANF. http://saranf.net/Le-syndrome-thoracique-aigu-une.html

[9] Centre de Reference Maladies rares labellisées (2007) Syndrome drépanocytaire majeur. Recommandations pour la prise en charge de la grossesse chez les femmes atteintes d'un syndrome drépanocytaire majeur. http://urgencesmondor.aphp.fr/IMG/pdf/drepano grossesse.pdf

[10] Muganyizi, P.S. and Kidanto, H. (2013) Sickle Cell Disease in Pregnancy: Trend and Pregnancy Outcomes at a Ter- 
tiary Hospital in Tanzania. PLoS ONE, 8, e56541. http://dx.doi.org/10.1371/journal.pone.0056541

[11] Ségbéna, A.Y., Messie, A.K., Kuéviakoé, L., Vovor, A., Gbadoé, A.D. and Assimadi, J.K. (2003) Situation de la drépanocytose au Togo. Actes des Journées scientifiques de l'Université de Lomé, Togo, 203-205.

[12] North, M.L., Piffaut, M.C., Duwig, I., Locoh-Donou, A.G. and Locoh-Donou, A.M. (1998) Detection of Haemoglobinopathies at Birth in Togo. Nouvelle Revue Française d'Hématologie, 30, 237-241.

[13] Rahimy, M.C., Gangbo, A., Codo, M., Gbedji, E. and Alihonou, E. (2001) Connaissance sur la drépanocytose et pratiques des femmes enceintes porteuses d'hémoglobine $\mathrm{S}$ ou $\mathrm{C}(\mathrm{Hb} \mathrm{S}$ ou $\mathrm{Hb} \mathrm{C})$ à Cotonou. African Child Health Journal, 3, 59-64.

[14] Addai, F.K., Wilson, J.B. and Quashie, F.J. (1992) Comparative Studies of Live Neonates in Maternal Sickle Cell Haemoglobinopathy in Ghana. Tropical and Geographical Medicine, 44, 312-316.

[15] Serjeant, G.R., Hambleton, I. and Thame, M. (2005) Fecundity and Pregnancy Outcome in a Cohort with Sickle CellHaemoglobin C Disease Followed from Birth. BJOG: An International Journal of Obstetrics \& Gynaecology, 112, 1308-1314. http://dx.doi.org/10.1111/j.1471-0528.2005.00678.x

[16] Serjeant, G.R., Singhal, A. and Hambleton, I.R. (2001) Sickle Cell Disease and Age at Menarche in Jamaican Girls: Observations from a Cohort Study. Archives of Disease in Childhood, 85, 375-378. http://dx.doi.org/10.1136/adc.85.5.375

[17] Assimadi, J.K., Gbadoe, A.D. and Nyadanu, M. (2000) L'impact familial de la drépanocytose au Togo. Archives de Pédiatrie, 7, 615-620. http://dx.doi.org/10.1016/S0929-693X(00)80128-1

[18] Ngô, C., Katem, G., Habibi, A., Benachi, A., Goffinet, F., Galacteros, F. and Haddad, B. (2010) Pregnancy in Sickle Cell Disease: Maternal and Foetal Outcomes in a Population Receiving Prophylactic Partial Exchange Transfusion. European Journal of Obstetrics \& Gynecology and Reproductive Biology, 152, 138-142. http://dx.doi.org/10.1016/j.ejogrb.2010.05.022

[19] Leborgne-Samuel, Y., Kadhel, P., Ryan, C. and Vendittelli, F. (2004) Sickle Cell Disease and Pregnancy. La Revue du Praticien, 54, 1578-1582.

[20] Leborgne-Samuel, Y., Janky, E. and Vendittelli, F. (2000) Drépanocytose et grossesse: Revue de 68 observations en guadeloupe. Journal de Gynécologie Obstétrique et Biologie de la Reproduction, 29, 86-93.

[21] Maitre, B., Habibi, A., Roudot-Thoraval, F., Bachir, D., DesvauxBelghiti, D., Galacteros, F. and Godeau, B. (2000) Acute Chest Syndrome in Adults with Sickle Cell Disease: Therapeutic Approach, Outcome and Results of Bronchoalveolar Lavage in a Monocentric Series of 107 Episodes. CHEST, 117, 1386-1392. http://journal.publications.chestnet.org/

[22] Vichinsky, E.P., Styles, L.A., Colangelo, L.H., Wright, E.C., Castro, O. and Nickerson, B. (1997) Acute Chest Syndrome in Sickle Cell Disease: Clinical Presentation and Course. Cooperative Study of Sickle Cell Disease. Blood, 89, 1787-1792.

[23] Koshy, M., Shisum, D., Burd, L., Orlina, A. and How, H. (1991) Management of Sickle Cell Anemia and Pregnancy. Journal of Clinical Apheresis, 6, 230-234. http://dx.doi.org/10.1002/jca.2920060412

[24] Howard, R.J. (1995) Pregnancy in Sickle Cell Disease in the UK: Results of a Multicentre Survey of the Effect of Prophylactic Blood Transfusion on Maternal and Fetal Outcome. BJOG: An International Journal of Obstetrics \& Gynaecology, 102, 947-951. http://dx.doi.org/10.1111/j.1471-0528.1995.tb10900.x

[25] El Shafei, A.M., Kaur, D.J., Kaur, S.A. and Al Sharqui, R.M. (1995) Indications for Blood Transfusion in Pregnancy with Sickle Cell Disease. Australian and New Zealand Journal of Obstetrics and Gynaecology, 35, 405-408. http://dx.doi.org/10.1111/j.1479-828X.1995.tb02153.x

[26] Odum, C.U., Anorlu, R.I., Dim, S.I. and Oyekan, T.O. (2002) Pregnancy Outcome in HbSS-Sickle Cell Disease in Lagos, Nigeria. West African Journal of Medicine, 21, 19-23.

[27] Serjeant, G.R. (2004) Outcome of Pregnancy in Homozygous Sickle Cell Disease. The American College of Obstetricians and Gynecologists. Obstetrics \& Gynecology, 103, 1278-1285. http://dx.doi.org/10.1097/01.AOG.0000127433.23611.54

[28] Ogedengbe, O.K. and Akinyanju, O. (1993) The Pattern of Sickle Cell Disease in Pregnancy in Lagos, Nigeria. West African Journal of Medicine, 12, 96-100.

[29] Idrissa, A., Omigbodun, A.O. and Adeleye, J.A. (1992) Pregnancy in Hemoglobin Sickle Cell Patients at the University College Hospital, Ibadan. International Journal of Gynecology \& Obstetrics, 38, 83-86. http://dx.doi.org/10.1016/0020-7292(92)90040-p

[30] Ashish, K., Raseswari, P. and Pruthviraj, S. (2008) Perinatal Outcome in Pregnancy with Sickle Cell Anemia. The Journal of Obstetrics and Gynecology of India, 58, 500-503. http://medind.nic.in/jaq/t08/i6/jaqt08i6p500.pdf

[31] Balaka, B., Kessie, K., Assimadi, K., N'dakena, K. and Baeta, S. (1994) Cœur drépanocytaire du nourrisson et anémie maternelle de la grossesse. Annales de Pédiatrie, 41, 382-387. 